\title{
The Effectiveness of Mathematics Learning using Learning Start With A Questions Model in Improving Mathematics Learning Ability
}

\author{
Dian Hidayat Tanjung \\ State University of Medan, Medan, Indonesia \\ tanjungmargana@gmail.com
}

\author{
Izwita Dewi \\ State University of Medan, Medan, Indonesia
}

\begin{abstract}
Problem formulation in this research is 1). Whether the learning model " learning start with a questions" can improve the effectiveness of mathematics learning in the seventh grade of Junior High School Muhammadiyah 57. 2). Whether by using the learning model " learning start with a questions can improve the students math learning ability of junior high school class in the cognitive domain. This study aims are 1). To know whether the learning model learning start with a questions can improve the effectiveness of mathematics learning in class VII junior high school. 2). To find out whether by using learning model learning start with a questions can improve students math learning ability junior high school class in the cognitive domain. By using the gain test, the percentage of the effectiveness of learning model of learning start with a question is $\mathbf{7 7 \%}$, in the experiment class, while the control class is obtained large percentage effectiveness $(9 \%)$. Based on the details of the results above, it can be concluded that learning mathematics using the learning model Learning Start With A Questions for students of junior high school effective on the material set in the Cognitive Student Area.
\end{abstract}

Keywords: learning starts with a question, mathematics learning.

\section{INTRODUCTION}

Mathematics is one branch of science that has an important role in the development of science and technology that is as forming rasoinal mindset and attitude-forming logical, critical care, and discipline. Mathematics as well as one of the basic sciences, both applied aspects as well as aspects of reasoning has an important role in the effort mastery of science and technology. This causes the math required to be taught from primary school education, secondary education, go to college. The fact that there are difficulties for students to understand math so that student learning outcomes is still much below the minimum completeness criteria.[1] Such conditions require the attention of various parties, especially the teachers should be able to apply active learning during the learning process.

In connection with the study of mathematics, there are many things that lead to poor learning ability of students, one of which is a lack of understanding of students while learning.[2] Therefore, to improve the ability to learn, it is not enough just to hear and see it, it takes the interaction between teachers and learners, and among learners, such as asking questions, discuss, and maybe even teach fellow. And from the observation can also be seen, that students just do the activity listened and recorded, which resulted in students can tend to get bored when the only activity that in a long time, no feedback from learners and no questions asked of participants learners.

Many factors affect to cause of the low or lack of student mathematics understading, one model used by the teacher.[3] For example, in learning oriented to the traditional approach puts learners in the learning process as a listener, contrary role of the teacher in the learning is very dominant.

Therefore, the study of mathematics requires a model that can enhance students' learning ability to stimulate students active in asking. The learning model Learning Start with a question is active learning that begins with a question, where students are directly involved in the learning process.[4] At the start with a model of Learning these questions required students active in asking the teacher gives the students the opportunity to read the material to be learned and share their thoughts or ideas with others in a group.

The statement from the researchers to conclude that the difficulty of students in a lesson and work on the problems not because students are not intelligent or less capable, but the lack of skills of students to ask and ineffectiveness active learning methods are used by theacher. Based on background of the problem, identify the problem, then problem in this research are: 1) is the learning models start with a questions can improve the effectiveness of mathematics in class VII Junior high school Terrain? 2.) Does using learning models start with a questions can improve the ability to learn math grade students of Junior high school Terrain in the cognitive domains?

\section{METHODOLOGY}

This type of research is experimental research, by comparing the ability of mathematics learning by using a model of learning start with a questions in the experimental class and did not use the model of learning start with a questions or by conventional methods in the control class that is done by giving a pre-test for knowing the initial ability of students and post test to determine the ability of the student's final.[5] 
TABLE 1. RESEARCH DESIGN

\begin{tabular}{|l|l|l|l|}
\hline Category & $\begin{array}{l}\text { Pre } \\
\text { test }\end{array}$ & Treatment & $\begin{array}{l}\text { Pos } \\
\text { test }\end{array}$ \\
\hline Eksperimen & $\mathrm{X}_{1}$ & $\begin{array}{l}\text { Learning start with } \\
\text { a question }\end{array}$ & $\mathrm{X}_{1}$ \\
\hline Control & $\mathrm{X}_{2}$ & Conventional & $\mathrm{X}_{2}$ \\
\hline
\end{tabular}

Information :

$\mathrm{X} 1=$ the ability to learn math using LSQ learning model in the experimental class.

$\mathrm{X} 2$ = the ability to learn math using conventional methods in the control class.

The population in this study were all students of class VII Junior high school. The sample was composed of two classes, with the details of class VII-A with 39 students as control class and class VII-B with 34 students as an experimental class.[6] Tests given to students describing the test shaped totaling 10 questions consisting of the initial test (pre-test) and final test (post-test) with each 5 items / test.

\section{RESULT}

Stages in this study were first tested for the research instrument, ie the validity of the test questions.

TABLE 2. VALIDITY RESULTS

\begin{tabular}{|c|c|c|c|}
\hline Item & $\begin{array}{c}\text { Question } \\
\text { number }\end{array}$ & validity score & Information \\
\hline 1 & 1 & 0,956342648 & Valid \\
\hline 2 & 2 & 0,412236357 & Valid \\
\hline 3 & 3 & 0,851531532 & Valid \\
\hline 4 & 4 & 0,418479646 & Valid \\
\hline 5 & 5 & 0,933877439 & Valid \\
\hline 6 & 6 & 0,763725355 & Valid \\
\hline 7 & 7 & 0,724967386 & Valid \\
\hline 8 & 8 & 0,760197874 & Valid \\
\hline 9 & 9 & 0,573204957 & Valid \\
\hline 10 & 10 & 0,786030737 & Valid \\
\hline
\end{tabular}

Its validity by looking at the results of the calculation, it can be seen that the above matter is Valid.

Having obtained the value of mathematics learning pengelolahan data can be performed to find the average value and standard deviation of variables. For more see clearly can be seen from the following table and data.

TABLE 3.THE FOLLOWING IS A SUMMARY DESCRIPTION OF EACH CLASS

\begin{tabular}{|c|c|c|c|c|}
\hline \multirow{2}{*}{ basic stats } & \multicolumn{2}{|c|}{ Eksperimen } & \multicolumn{2}{c|}{ Control } \\
\cline { 2 - 5 } & Pre-test & Post-test & $\begin{array}{c}\text { Pre- } \\
\text { test }\end{array}$ & $\begin{array}{c}\text { Pos- } \\
\text { test }\end{array}$ \\
\hline N & 34 & 34 & 39 & 39 \\
\hline Mean & 57,29 & 84,2 & $71_{r} 69$ & 76,5 \\
\hline $\begin{array}{c}\text { standard } \\
\text { deviation }\end{array}$ & 29,9 & 10,7 & 14,6 & 14,9 \\
\hline
\end{tabular}

\section{A. Normality test}

Normality test is intended to determine whether the obtained data distribution norms or not. To determine the normality test X1 and X2 variables used chi square formula at significant level with the criteria count $\alpha=0,05 \chi^{2 \text { count }}<\chi^{2}$ table the normal distribution of data.[6]

\begin{tabular}{|c|c|c|c|}
\multicolumn{5}{|c}{ TABLE. 4 NORMALITY TEST } \\
\hline Class & $\chi^{2}$ count & $\chi^{2}$ table & information \\
\hline 1. Pre-test & 9,678735515 & 12,592 & Normal \\
2. Post-test & 7,216100597 & 11,07 & Normal \\
\hline Control & & & \\
1. Pre-test & 11,58780328 & 12,592 & Normal \\
2. Post-test & 6,322880858 & 12,592 & Normal \\
\hline
\end{tabular}

From the table above it can be seen that $\chi^{2}$ count The second sample is less than $\chi^{\text {2table }}$, This shows that both the normal distribution of the data used, because fulfilling the criteria count $\chi^{2 \text { count }}<\chi^{2 \text { table }}$

\section{B. Homogeneity test}

After learning that the sample comes from a population that is normally distributed, the next step is to test the homogeneity. Homogeneity test is used to determine whether the samples have the same variance. Homogeneity test in this study using a significant tarap $\alpha=0,05[7]$.

TABLE 5. HOMOGENEITY TEST

\begin{tabular}{|c|c|c|}
\hline Pre-test & Variants & Information \\
\hline Eksperimen & 715,8431373 & Greatest \\
\hline Control & 237,4199 & Smallest \\
\hline
\end{tabular}

Based on the above table, by comparing the largest variant with the smallest variant, then obtained $\mathrm{F}_{\text {count }}>\mathrm{F}_{\text {table }}$, then the data sample pre-test experimental and control is not homogeneous.

TABLE 6. HOMOGENEITY TEST

\begin{tabular}{|c|c|c|}
\hline Post-test & Varian & keterangan \\
\hline Eksperimen & 80,32888 & Smallest \\
\hline Kontrol & 246,41425 & Greatest \\
\hline
\end{tabular}

Based on the above table, by comparing the largest variant with the smallest variant, then obtained $\mathrm{F}_{\text {count }}>\mathrm{F}_{\text {table }}$, then the data sample Post-test experimental and control is not homogeneous.

\section{Gain Test}

To determine students' mathematics learning outcome. Gain Test calculations can be obtained from the pre-test and post-test value of each class is experimental class and control class, As the following table:

TABLE 7. GAIN TEST

\begin{tabular}{|c|c|c|}
\hline Class & Calculation of Gain Test & Criteria \\
\hline Eksperimen & $\mathbf{0 , 7 6 7}$ & High \\
\hline Control & $\mathbf{0 , 0 8 8}$ & Low \\
\hline
\end{tabular}


Gain of Test table above, to calculate the value of gain is pretty, can be sought from operations perhingan value Posttest and pre-test at each grade. Then the value obtained for the Class Experiment Gain Control of 0.767 and 0.088. Based on the test criteria for a class experiment Gain Gain High has the following criteria, while for Class Low Control has the following criteria.

\section{CONCLUSION}

Based on the results of research and discussion, we can conclude that through Model start learning with a questions can improve the ability of students in the subject of mathematics Association 57 students of class VII Junior High School. It can be seen from the average value of completeness and activeness of students in mathematics implementing Learning Model start learning with a questions which increased until it reaches an indicator of success.

\section{REFERENCE}

[1] Slameto. 2003. Pengertian Belajar \& Pengertian Pembelajaran. Akademia, (Online).

[2] Slavin, Warli. 2012. Educational Psychology:Theory and PracticeEighty. United States Of American:Pearson Education, Inc.(http://www.academia.edu/8793199/Pengertian_Belajar_a nd_Pengertian_Pembelajaran).

[4] Howard. 2008. Learning Start With A Questions (LSQ). (Online).(http : $\quad / / \quad w w w \quad$ fa dillawekay.wordpress.com/2013/04/24/ model - learning - start - with - a-questions/,

[5] Sugiyono. 2013. Metode Penelitian Pendidikan Pendekatan Kuantitatif, Kualitatif dan $R \& D$. Bandung : Alfabeta.

[6] Burhan Bungin, Metodologi Penelitian Kuantitatif, Jakarta :Kencana, 2006.

[7] Syofian. 2012. Statistik Parametrik untuk Penelitian Kuantitatif Dilengkapi dengan perhitungan Manual dan Aplikasi SPSS $\begin{array}{lllll}\text { Versi } & 17 . & \text { Jakarta } & \text { : } & \text { Bumi Aksa }\end{array}$ 
